\title{
PEMANFAATAN PEMROGRAMAN VISUAL SEBAGAI ALTERNATIF PEMBUATAN MEDIA BELAJAR BERBASIS GAME DAN ANIMASI
}

\author{
Dedi Gunawan, dan Fatah Yasin Al Irsyadi \\ Program Studi Informatika \\ Fakultas Komunikasi dan Informatika, Universitas Muhammadiyah Surakarta \\ Jl. A. Yani Tromol Pos I Pabelan, Kartasura, Surakarta, Indonesia \\ dedi.gunawan@ums.ac.id \\ fatah.yasin@ums.ac.id
}

\begin{abstract}
Visual programming is the one programming technique in computer Science which aims to give easy understanding in writing code program. The main users of visual programming are students and people who have no experiences in making computer code and lack of computer programming language. Visual programming gives advantages to develop any kind of application software such as game and application related to education. This research was conducted to the teachers who teach Al-Quran for children learning in order to know the benefit of using visual programming in terms of creating an animation and game education. Several approach has been applied in this research. The first is surveying the knowledge in computer programming by using questioners. Following that, we provide a training of using visual programming and the last is conduction survey in order to know the progress of learning accuisiton.Based on the questioner's data,it can be found that visual programming is very useful to introduce computer programming for people who have limited computer background. The data shows that $60 \%$ respondent believe that the visual programming is easy to follow, while the rest says it is hard to do. Furthermore, some of the participants are able to create simple education game.
\end{abstract}

Keywords: Visual programming, Game education, Animation

\section{PENDAHULUAN}

Saat ini penggunaan Teknologi Informasi telah merambah pada semua bidang, termasuk bidang pendidikan khususnya pendidikan agama Islam. Metode pendidikanpun sudah dikembangkan sedemikian rupa agar bisa mempermudah para siswa dalam belajar salah satunya adalah pemanfaatan animasi komputer dalam proses kegiatan belajar. Didukung dengan perkembangan perangkat komputer yang sangat cepat khususnya dibidang grafis dan pengolahan sura, maka pemanfaatan animasi komputer sebagai sarana edukasi tentunya akan memberikan manfaat yang signifikan terhadap pemahaman siswa didik. Selain menyenangkan dan tidak membosankan, penggunaan animasi komputer sebagai sarana pembelajaran juga terbukti memberikan efek positif terhadap siswa didik.Beberapa penelitian seperti yang dilakukan oleh [1] dan [2] menunjukkan 
bahwa pemanfaatan animasi komputer sebagai media pembelajaran dapat meningkatkan pemahaman materi belajar dengan cepat, hal ini disebabkan karena proses belajar dilakukan dengan cara yang menyenangkan dan menarik.

Akan tetapi disisi lain guru-guru TPQ juga masih banyak memiliki kendala yang yang harus dipikirkan dengan baik yaitu bagaimana membuat animasi komputer edukatif yang bisa meningkatkan kemampuan kognitif siswa. Sebenarnya, media belajar berbasis animasi yang edukatif sudah bisa ditemukan dengan mudah baik secara online maupun dari buku-buku, namun perlu kita sadari bahwa sebagian besarmateri yang disajikan dianggap kurang relevan dengan materi yang diajarkan di taman pendidikan Al-Quran setempat. Sehingga para guru diharapkan mampu secara mandiri mengembangkan media pembejalaran edukatif yang berbasis animasidan sesuai dengan kurikulum serta visi misi dari lembaga pendidikan. Salah satu kendala yang dihadapi oleh para guru di taman pendidikan Al-Quran di kecamatan pasar kliwon adalah kurangnya kemampuan dan ketrampilan khusunya dalam membuat mediatersebut khususnya ketrampilan penggunaan software untuk membuat animasi, ditambah lagi dengan pengetahuan mereka yang masih minim tentang proses dan teknik pembuatan animasi masih sangat kurang. Sehingga itu kegiatan penelitian ini dimaksudkan untuk mencari tahu apakah pemrograman visual bisa dipahami dengan mudah sehingga bisa diterapkan dalam kegiatan belajar mengajar dengan memberikan pelatihan pembuatan media pembelajaran edukatif yang bebasis animasi melalui pemanfaatkan pemrograman visual bagi para guru dan penggiat Taman Pendidikan Alquran (TPQ) di wilayah Pasar Kliwon. Peserta yang diundang dalam kegiatan ini berjumlah 20 orang, akan tetapi yang bisa hadir hanya 12 orang,peserta yang hadir adalah rekomendasidari koordinator kegiatan.

Apakah pemrograman visual mudah dipahami oleh para guru taman pendidikan al-quran untuk membantu dalam pembuatan media belajar dan game edukasi .

\section{Scratch}

Scratch adalah sebuah bahasa pemrograman yang tersedia secara gratis dan dibuat oleh Lifelong Kindergarten Group dari Massachusetts Institute of Technology (MIT) dengan lebih dari 5 juta pengguna terdaftar. Versi terbaru Scratch, Scratch 2.0 dapat digunakan secara online di http:// scratch.mit.edu/create/ juga dapat diunduh untuk dikerjakan secara offline. Scratch 2 dapat di unduh di http://scratch.mit.edu/ scratch2download/. Scratch didesain untuk menjadi asyik, edukatif, dan mudah untuk dipelajari. Scratch bisa digunakan untuk membuat cerita interaktif, permainan, seni (art), simulator, dan masih banyak lagi. Scratch bahkan mempunyai editor menggambar dan editor suara sendiri.Pengguna dapat menyusun sebuah program di Scratch dengan menarik dan menggeser balok-balok dari Palet Balok kemudian menggabungkan mereka ke balok lain seperti puzzle jigsaw. Struktur dari beberapa balok atau lebih disebut skrip. Metode pemrograman ini (menulis kode dengan balok) juga bisa disebut "pemograman geser dan menaruh", atau, dalam Bahasa Inggrisnya, "drag and drop programming".Scratch digunakan di sekolah-sekolah di segala penjuru dunia sebagai media untuk mengenalkan pemrograman dasar ke anak-anak. Scratch juga digunakan di luar sekolah. Anak-anak, dan bahkan orang dewasa, menambah pengertian tentang berbagai bentuk pemrograman lewat Scratch. Di Indonesia, Scratch banyak digunakan kursus pemrograman komputer sebagai media pembelajaran. 


\section{Fitur Scratch :}

1. Built in library : library pada scratch merupakan kumpulan karakter dan background yang disediakan oleh scratch secara defaul. Library ini bisa dimanfaatkan oleh user untuk membuat animasi maupun media pembelajaran berbasis animasi komputer. Beberapa library yang ada di scratch diantaranya, karakter atau objek, latar belakang, dan sound.

2. Sound Recorder : Fasilitas sound recorder digunakan untuk merekam suara dari user.

3. Export resources : Fasilitas ini bisa digunakan oleh user ketika akan mengguanakan file seperti gambar dan suara yang sudah dimiliki oleh user untuk dimasukkan kedalam program.

4. Block script : Block script merupakan block yang bisa dimanfaatkan untuk membuat kontrol dari aplikasi yang kita buat. Block script memiliki beberapa kategori yang masing-masing memiliki fungsi yang berlainan.

5. Publish project : Fitur ini digunakan ketika kita akan mempublis hasil pekerjaan kita secara luas melalui internet. File yang sudah dipublis nantinya akan tersimpan di server scratch dan bisa diunduh oleh user lain

Secara umum tujuan kegiatan pengabdian ini adalah untuk meningkatkan kemampuan para pendidik di taman pendidikan Al-Qur'an daerah Pasar Kliwon dalam membuat media pembelajaran edukatif yang berbasis animasi sehingga diharapkan materi pembelajaran makin mudah dipahami untuk selanjutnya diamalkan dalam kegiatan belajar mengajar setiap hari. Secara khusus kegiatan ini bertujuan untuk meningkatkan kemampuan peserta dalam menggunakan scratch sebagai salah satu software pemrograman visual.

Sedangkan manfaat yang diharapkan dari kegiatan pengabdian ini adalah sebagai berikut:
1. Para Guru taman pendidikan Al-Qur'an mampu menggunakan scratch untuk membuat media pembelajaran edukasi berbasis animasi yang nantinya bisa diterapakan dalam kegiatan belajar mengajar di TPQ.

2.. Meningkatkan silaturahim dan kerjasama antara UMS dengan para guru taman pendidikan Al-Quran di daerah Pasar Kliwon.

\section{METODE PENELITIAN}

\section{Alat dan bahan}

Alat dan bahan yang digunakan dalam pengabdian ini diantaranya:

a. Beberapa komputer (personal computer) atau laptop yang sudah diinstall softwareScratch.

b. LCD proyektoratau TV plasma untuk menyampaikan materi pelatihan.

c.. Modul pelatihan pemrograman visual dengan scratch.

d.. Perangkat multimedia yang digunakan untuk proses perekaman suara pada media pembelajaran berbasis animasi komputer.

e.. Perangkat-perangkat pendukung (biodata peserta, daftar hadir peserta, lembar kuisioner)

\section{Tata Laksana Kegiatan}

Metode kegiatan dalam Pelatihan ini meliputi:

a. PreTest tentang penguasaan materi pelatihan.

b. Presentasi (Ceramah) tentang latar belakang animasi dan alasan yang mendasari akan manfaat dari penggunaan animasi dalam proses belajar mengajar.

c. Praktek langsung membuat media belajarberbasis animasi yang sederhana.

d. PostTest tentang penguasaan materi pelatihan. 
Pelatihan ini dilaksanakan di J1.Cilosari 214, Semanggi, Pasar Kliwon, Surakarta. Fasilitator pelatihan adalah staf pengajar dan mahasiswa program studi Informatika Fakultas Komunikasi dan Informatika Universitas Muhammadiyah Surakarta

\section{HASIL DAN PEMBAHASAN}

\section{Analisa dan pelaksanaan}

Jumlah peserta yang direncanakan dalam penelitian ini adalah 20 orang, yang berprofesi sebagai guru dan penggiat TPQ di daerah pasar kliwon. Adapun daftar peserta yang terlibat adalah sebagai berikut:

$\begin{array}{ll}\text { Fandra Eka } & \text { Muhammad } \\ \text { Muh. Rosyid Ridho } & \text { Aulia Asifati Asfa } \\ \text { Qooimatul Amanah } & \text { Sholikah } \\ \text { Putri Setyaningtyas } & \text { Irwan Firman } \\ \text { Alexander Miftahul F } & \text { Arif Nur C } \\ \text { Ismi Salimah } & \text { Fajar Adi N }\end{array}$

Tema pelatihan bagi para pendidik taman pendidikan Al-Quran daerah Pasar Kliwon adalah ingin memberikan pengtahuan kepada para guru tentang pemanfatan software aplikasi scratchsebagai sarana untuk membuat media pembelajaran berbasis animasi sehingga diharapakan proses penyampaian materi belajar bisa lebih mudah dipahami oleh para siswa.

Proses kegiatan ini berjalan dengan lancar selain itu juga peserta dengan serius dan antusias mengikuti pelatihan dari awal sampai akhir. Proses pelatihan dipandu oleh timyang beranggotakan mahasiswa dengan menggunakan layar dan TV Plasma projektor, serta beberapa Laptop sehingga sangat membantu penyampaian materi pelatihan. Selain itu peserta juga sangat aktif bertanya khususnya mengenai hal-hal yang bersifat teknis seperti cara membuat animasi gerak, memasukkan suara dan mengganti background animasi.
Pengetahuan peserta pelatihan dianalisa melalui pengisian kuisioner sebanyak dua kali yang diisikan pada awal dan akhir pelatihan. Kuisioner berisi 10 pernyataan, peserta diminta untuk memilih jawaban YA atau TIDAK. Petanyaan pada kuestioner yang diberikan kepada peserta sebelum pelatihan dilaksanakan diantaranya adalah :

1. Apakah anda sudah familiar dengan komputer

2. Program komputer apa paling sering anda gunakan

3. Apakah anda setuju dengan pembelajaran berbasis komputer

4. Menurut anda apakah pembelajaran berbasis komputer dengan animasi dapat meningkatkan pemahaman siswa dengan baik

5. Pernahkan anda membuat media pembelajaran berbaisanimasi komputer ?

6. Tools atau software apakah yang menurut anda bisa digunakan untuk membuat media pembelajaran berbasis komputer animasi

7. Apakah anda mengetahui proses pembuatan media belajar yang berbasis animasi

8. Apakah anda mengetahui istilah pemrograman visual

9. apakah anda berfikir membuat media pembelajaran berbasis animasi itu sulit

Kuisioner diberikan kepada peserta pelatihan sebelum dan sesudah pelatihan. Peserta pelatihan berjumlah 12 orang dan semua diberi kuesioner. Namun hanya 10 kuesioner yang dikembalikan setelah pelatihan.

Pertanyaan pertama pada kuestioner bertujuan untuk menggali informasi apakah para peserta sudah terbiasa menggunakan komputer atau belum. sehingga ketika menyampaikan materi bisa lebih tepat, khusunya mengenai hal-hal teknis dan 
istilah-istilah mengenai komputer. dengan komputer, sehingga ketika Berdasarkan data dari kuesioner yang melakukan pelatihan dengan materi yang diperoleh terlihat bahwa menyatakan bahwa $100 \%$ atau semua peserta sudah familiar sedikit lebih sulit para peserta mampu mengatasinya secara pribadi.

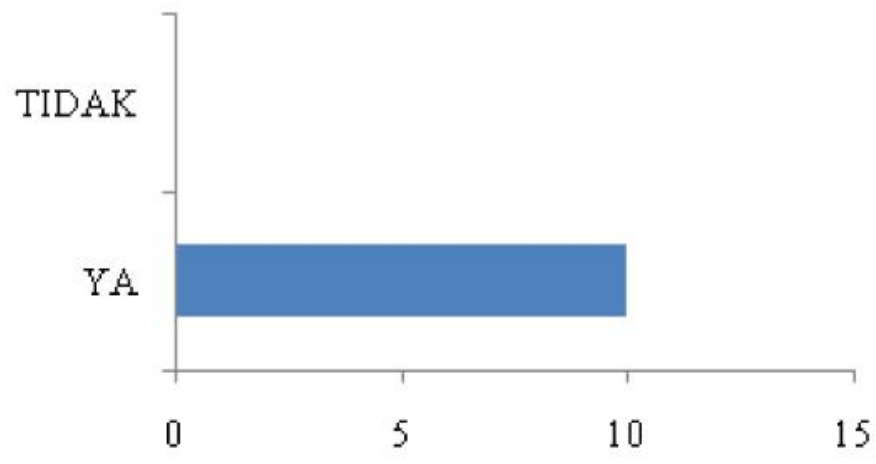

Gambar 1. Peserta sudah memiliki dasar penggunaan komputer

Pertanyaan yang ke dua adalah mengenai program apa yang sering dipakai oleh peserta pelatihan selama menggunakan komputer. Dari data kuesioner telihat bahwa $60 \%$ dari peserta yang hadir sudah cukup menguasai tentang microsoft word.

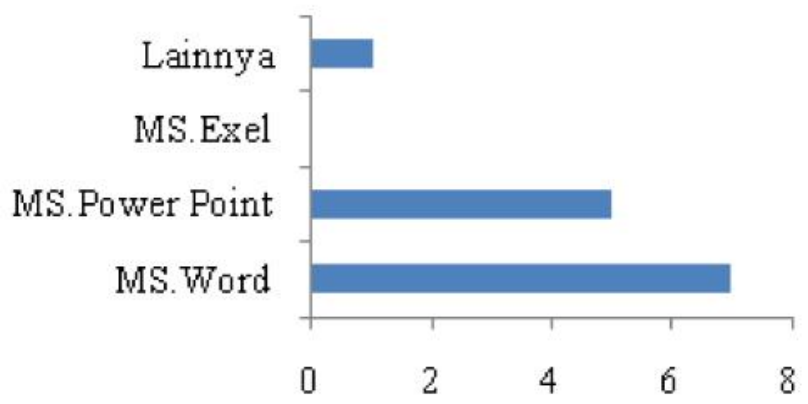

Gambar 2. Program komputer yang sudah dikuasai peserta

Ketika kita sudah mengetahui program apa yang paling dikuasai oleh peserta pelatihan maka kita bisa menyesuaikan tingkat kesulitan atau kerumitan materi pembuatan media pembelajaran berbasis animasi komputer yang nantinya akan diberikan kepada peserta, sehingga peserta mampu memahami dengan baik.

Pertanyaan ke-3 sampai ke-5 berkaitan dengan pembanfaatan media pembelajaran berbasis animasi komputer atau permainan komputer sebagai salah satu cara untuk menyampaikan materi pembelajaran. tujuan dari pertanyaan ini adalah apakah peserta pelatihan yakin bahwa nantinya ketika hasil pelatihan diterapkan di lingkungan yang sesungguhnya ke peserta didik meraka akan setuju. Kuesioner menjunjukkan bahwa $90 \%$ peserta setuju bahwa pembelajaran menggunakan media komputer akan bermanfaat dan hanya $10 \%$ peserta tidak setuju tentang hal tersebut. Pertanyaan ini diikuti dengan petanyaan berikutnya adalah tentang kemudahan peserta didik dalam memahami materi melalui media beajar berbasis animasi. 


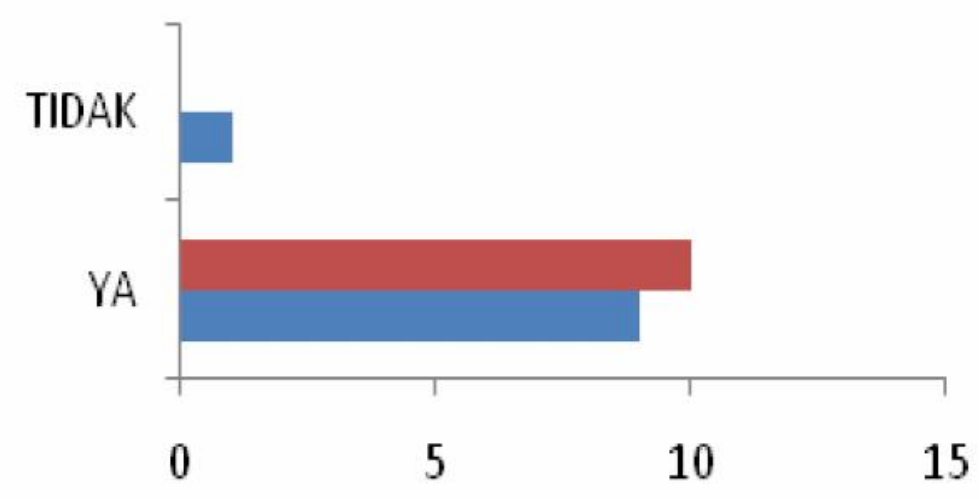

Gambar 3. Pembelajaran berbasis komputer animasi dapat meningkatkan pemahaman siswa

Selain itu, penulis juga memberikan pertanyaan di dalam kuesioner untuk mengetahui apakah para peserta pelatihan pernah membuat media belajar berbasis aniamsi komputer. Data kueisoner menunjukkan bahwa seluruh peserta belum pernah membuat media pembelajaran berbasis animasi kombuter. akan tetani sebagian besar dari peserta sudah mengetahui tools yang digunakan untuk membuat media belajar berbasis animasi. Sebanyak $80 \%$ peserta pelatihan menyebutkan macromedia flash adalah software yang bisa digunakan untuk hal tersebut, $10 \%$ menjawab power point dan $10 \%$ belum mengetahui tools apa vang bisa digunakan untuk hal tersebut

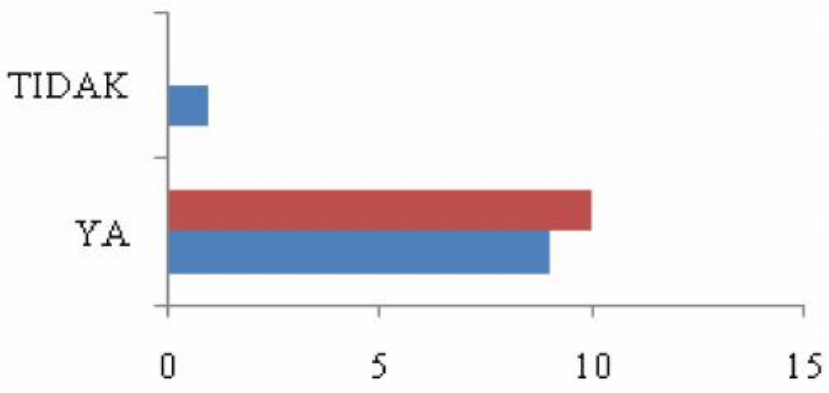

Gambar 3. Pembelajaran berbasis komputer animasi dapat meningkatkan pemahaman siswa

Selain itu, penulis juga memberikan pertanyaan di dalam kuesioner untuk mengetahui apakah para peserta pelatihan pernah membuat media belajar berbasis aniamsi komputer. Data kueisoner menunjukkan bahwa seluruh peserta belum pernah membuat media pembelajaran berbasis animasi komputer, akan tetapi sebagian besar dari peserta sudah mengetahui tools yang digunakan untuk membuat media belajar berbasis animasi. Sebanyak $80 \%$ peserta pelatihan menyebutkan macromedia flash adalah software yang bisa digunakan untuk hal tersebut, $10 \%$ menjawab power point dan $10 \%$ belum mengetahui tools apa yang bisa digunakan untuk hal tersebut 


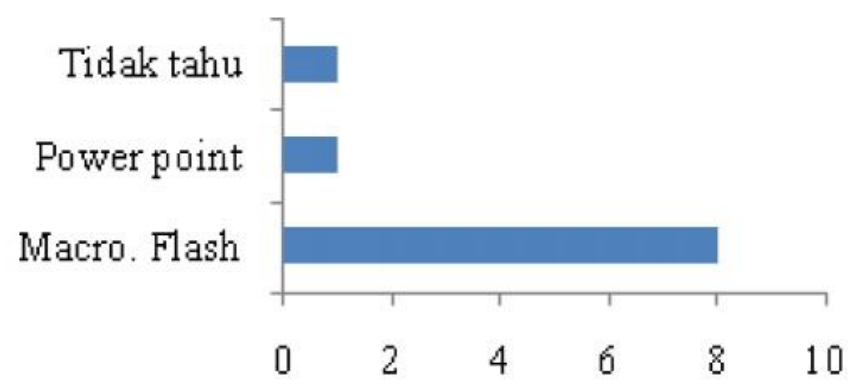

Gambar 4. Tools yang bisa digunakan untuk membuat media pembelajaran berbasis animasi

Setelah mengetahui latar belakang kemampuan komputer dan sudut pandang peserta mengenai pemanfaatan komputer sebagai media pebelajaran, langkah berikutnya adalah menanyakan apakah peserta pelatihan mengetahui proses pembuatanmedia pembelajaran berbasis animasi komputer. Data dari reponden mengindikasikan bahwa $80 \%$ peserta belum mengetahui prosespembuatanmedia pembelajaran berbasis animasi komputer, tetapi $20 \%$ peserta lainnya sudah mengetahui hal tersebut meskipun belum pernah membuatnya.

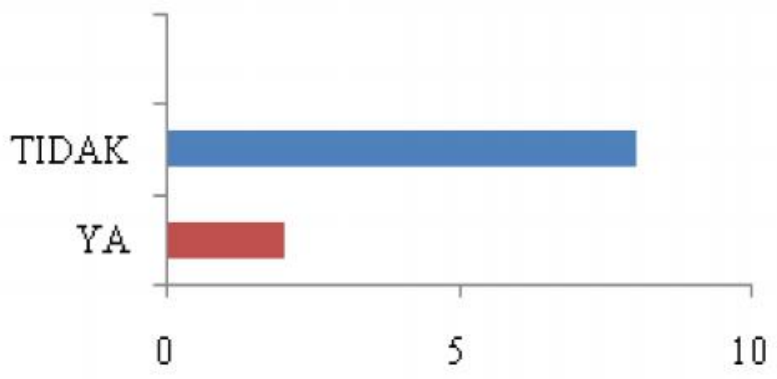

Gambar 5. Pengetahuan tentang proses pembuatan media pembelajaran berbasis animasi

Pertanyaan terakhir berkaitan dengan gambaran peserta tentang kesulitan membuat media pemberlajaran berbasis animasi dengan komputer, data dari responden menunjukkan $100 \%$ responden beranggapan bahwa membuat animasi untuk media pembelajaran adalah hal yang sulit dilakukan. Sehingga penulis membagi pelatihan ini menjadi dua sesi yaitu memberikan materi secara teoritis melalui presentasi dan kedua adalah praktek langsung yang disertai dengan tanya jawab.
Kegiatan pertama dari pelatihan adalah pemateri memberikan pengertian dan penjelasan mengenai apa yang dimaksud dengan media pembelajaran berbasis animasi komputer dan pemrograman visual yang bertujuan agar peserta memiliki konsep yang tepat mengenai kedua hal tersebut. Selanjutnya pemateri memberikan langkahlangkah praktis untuk memulai membuat media pembelajaran berbasis animasi komputer, dari mulai membuat gambar materi pembelajaran sampai memasukkan 
suara dan background. Kegiatan yang kedua adalah peserta melakukan praktik secara langsung dengan pendampingan oleh fasilitator pelatihan meskipun pada akhirnya peserta belum bisa menyelesaikan atau membuat suatu media pembelajaran berbasis animasi komputer secara utuh dikarenakan perlunya memikirkan konsep materi yang tepat dan juga keterbatasan waktu pelatihan, akan tetapi konsep dasar membuat media pembelajaran berbasis animasi komputer sudah mereka pahami. Hal ini terlihat dari hasil kuesioner yang diberikan setelah kegiatan pelatihan selesai dilaksanakan.

Setelah diberikan pelatihan tentang pemanfaatan pemrograman visual untuk membuat media pembelajaran berbasis animasi komputer, peserta mulai memahami langkah dan proses pembuatan media pembelajaran berbasis animasi komputer serta mengetahui tool apa yang diperlukan untuk membuat media pembelajaran berbasis animasi komputer dengan mudah, selanjutnya peserta diberikan kuesioner yang merupakan indikator mengenaipembahaman pemrograman visual untuk membuat media pembelajaran berbasis animasi komputeroleh peserta pelatihan.
Pertanyaan kuesioner yang diberikan kepada peserta pelatihan setelah kegiatan pelatihan dilakasanakan antara lain :

1. Apakah anda menyukai pelatihan ini

2. Apakah pelatihan memberi manfaat bagi peserta

3. Apakah peserta sudah memahami proses pembuatanmedia pembelajaran berbasis animasi komputer

4. Apakah peserta masih berfikir membuat media pembelajaran berbasis animasi komputer edukasi sederhana itu sulit

5. Apakah peserta berkeinginan membuat media pembelajaran berbasis animasi komputer yang lebih menarik

6. Apakah peserta sudah memahami pemrograman visual

7. Apakah peserta tertarik untuk belajar pemrograman visual

8. Apakah pemrograman visual terasa sulit

9. Apakah peserta perlu memahami bahasa pemrograman tertentu untuk bisa memahami pemrograman visual.

Dari data kuesioner untuk pertanyaan pertama semua peserta menjawab sangat menyukai pelatihan ini. Selain itu juga pelatihan yang diberikan memberikan manfaat bagi para peserta.

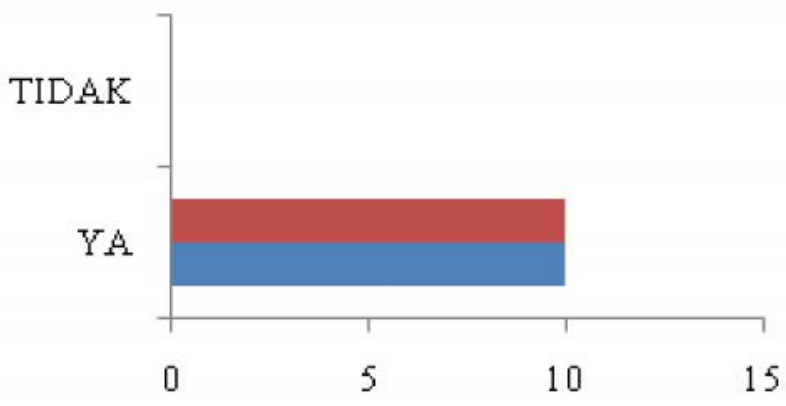

Gambar 6. Antusiasme peserta dan manfaat pelatihan

Dalam pelatihan ini selain mendapatkan teori tentang pemrograman visual peserta juga langsung mempraktekan membuat media pembelajaran berbasis animasi komputer edukasi yang sederhana.
Selanjutnya peserta diberi pertanyaan tentang proses pembuatan media pembelajaran berbasis animasi komputer. Data dari responden mengindikasikan bahwa peserta mengalami peningkatan pemahaman yang 
signifikan tentang proses pembuatan media belajar berbasis animasi komputer dari yang sebelumnya hanya $20 \%$ peserta menjadi
$100 \%$ peserta mamahami proses pembuatan media belajar berbasis animasi komputer

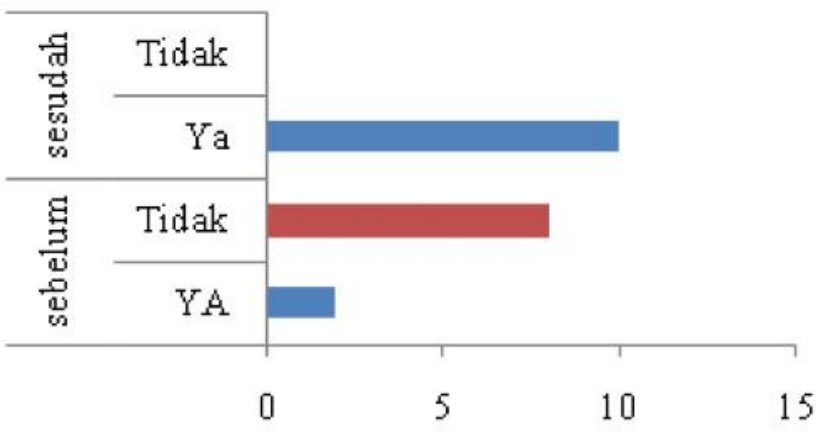

Gambar 7. Perbandingan pengtahuan peserta tentang proses pembuatan media pembelajaran sebelum dan sesudah pelatihan

Selain menanyakan hal tersebut di atas, fasilitator juga memberikan pertanyaan tentang pengetahuan mengenai pemrograman visual. Dari data kuesioner terlihat bahwa seluruh peserta sudah cukup memahami apa dan bagaimana memanfaatkan pemrograman visual untuk pembuatan media pembelajaran berbasis animasi komputer edukasi. Jika dibandingkan dengan kondisi sebelum pelatihan maka terliahat bahwa pemahaman peserta tentang hal tersebut sudah sangant jauh berbeda dan mengalami peningkatan yang signifikan.

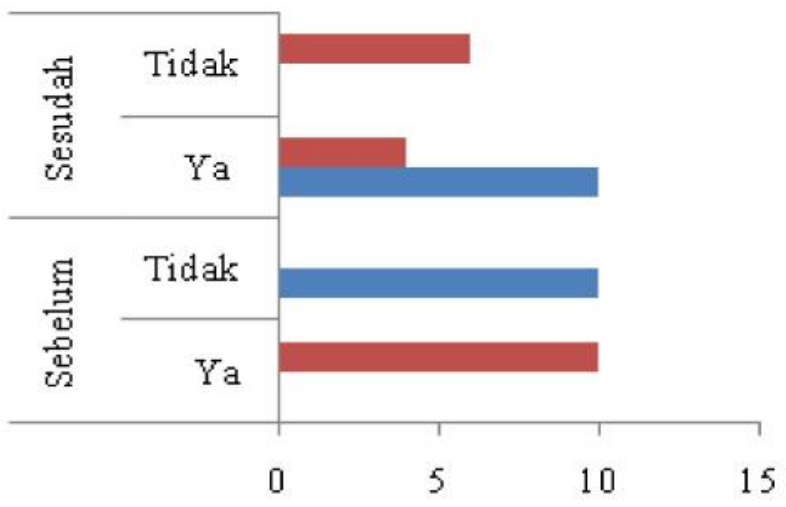

Gambar 8. Pengetahuan tentang pemrograman visual dan tingkat pemahaman peserta tentang pemrograman visual

Dari grafik di atas terlihat bahwa sesudah mengikuti pelatihan peserta mulai familiar dengan pemrograman visual yang terbutkti dari $60 \%$ peserta menjawab bahwa pemrograman visual tidak terasa sulit bagi peserta dan $40 \%$ lainnya masih menganggap bahwa pemrograman visual teresa sulit.

Pertanyaan terakhir adalah menanyakan kepada peserta tentang ketrampilan apa yang perlu dikuasai untuk 
membuat media pembelajaran berbasis animasi komputer edukasi dengan pemrograman visual khususnya ketrampilan atau pemahaman tentang bahasa pemrograman. Data kuesioner menunjukkan bahwa semua peserta berpendapat untuk bisa memahami pemrograman visual peserta tidak perlu mempelajari bahasa pemrograman khusus seperti PHP, HTML, JAVA dan yang lainnya.

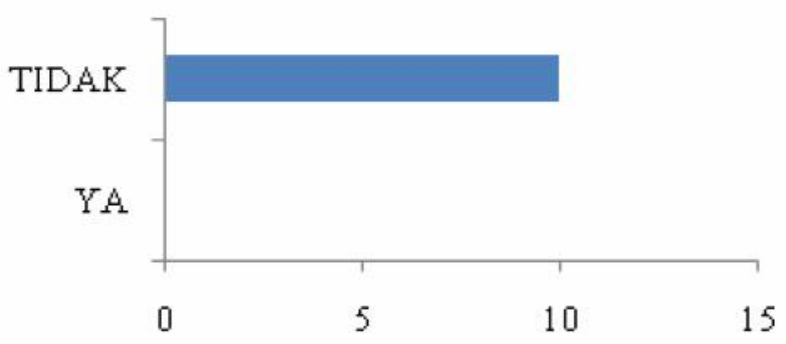

Gambar 9. Peserta tidak perlu mengetahui bahasa pemrograman terntu untuk bisa memahami pemrograman visual.

Petanyaan terakhir ini sekaligus menunjukkan bahwa peserta sudah memahami dan mampu menggunakan tool atau software pemrograman visual dengan baik sehingga untuk membuat media pembelajaran berbasis animasi komputer adukasi yang sederhana para peserta tidak perlu mempelajari bahasa pemrogrmaman tertentu yang tergolong sulit dan membingungkan dimana hal ini ditunjukkan pada Gambar 8 .

\section{a. Keberhasilan Kegiatan}

Indikator utama untuk menunjukkan keberhasilan pelaksanaan pelatihan Pembuatan media pembelajaran berbasis animasi komputeredukasi dengan pemrograman visualini terletak pada antusias para peserta dalam memberikan umpan balik dari pernyataan-pernyataan yang disampaikan sebelum dan sesudah pelatihan. Terlihat nampak adanya peningkatan pengetahuan tentang kegunaan dan pemanfaatan software pemrograman visualdalam menunjang produktifitas mereka sekaligus peserta sudah mampu mengaplikasikan dan mampu membuat media pembelajaran berbasis animasi komputer edukasi yang sederhana.

\section{SIMPULAN DAN SARAN}

\section{Simpulan}

Data dari kuesioner menunjukkan bahwa mayoritas para pengajar di taman pendidikan Al-Qur'an daerah Pasar kliwon setuju bahwa penggunaan teknologi komputer dapat meningkatkan pemahaman siswa didik lebih cepat. Para guru juga bisa memanfaatkan pemrograman visual yang merupakan model pemrograman yang mudah dipahami serta menyatakan setuju bahwa pemrograman visual mudah diikuti bahkan oleh orang yang memiliki pengetahuan terbatas tentangan teknologi komputer. Dengan memafaatkan pemrograman visual para guru di taman pendidikan al-quran daerah pasar kliwon mampu membuat sebuah media pembejaran yang bebasis animasi dan juga game edukasi dengan mudah meskipun masih sangat sederhana.

\section{Saran}

Untuk kegiatan pengabdian selanjutnya diharapkan kegiatan tidak hanya berfokus pada penyusunan blok kode program saja melainkan ada bagian kusus yang memjelaskan dengan detail 
cara mengolah suara yang akan dipakai pada game edukasi mengingat suara pada game memiliki peranan yang sangat penting.

\section{PERSANTUNAN}

Tim pengabdian mengucapkan terima kasih kepada semua pihak yang membantu atas terlaksananya kegiatan ini diantaranya yaitu Lembaga Penenelitian dan Pengabdian kepada Masyarakat Universitas Muhammadiyah Surakarta dan Para penggiat taman pendidikan Al-Qur'an Kecamatan Pasar Kliwon.

\section{DAFTAR PUSTAKA}

Gunawan, Dedi. 2000. Modul Pembelajaran Interaktif Elektronika Dasar untuk Program Keahlian Teknik Audio Vidio di SMK Muhammadiay 1 Sukoharjo Menggunakan Macromedia Flash 8. Jurnal KomuniTi, Vol. 2, No. 1, Juni 2010

Zainul, Ahmad Arifin. 2013. Pemanfaaan media animasi dalam peningkatan hasil belajar pada pembelajaran sholat kelas $V$ di SDN 2 semangkak Klaten Jawa Tengah. digilib.uin-suka.ac.id. 2013 